$\mathrm{A} \mathrm{J}_{\mathrm{sin}} \mathrm{H}$

Received : 13.10.2015

Revised : 06.11.2015

Accepted : 19.11.2015

Members of the Research Forum

Associated Authors:

${ }^{1}$ Department of Fruit Science, Dr.

Y.S. Parmar University of

Horticulture and Forestry, Nauni,

SOLAN (H.P.) INDIA
Author for correspondence : WINEET CHAWLA

Department of Agriculture, Baba Farid College, BATHINDA (PUNJAB) INDIA

Email : wineetchawla@gmail.com
THEASIAN JOURNAL OF HORTICULTURE

Volume 10 | Issue 2 | December, 2015 | 257-261

Visit us -www.researchjournal.co.in

RESEARCH PAPER

DOI : 10.15740/HAS/TAJH/10.2/257-261

\title{
Effect of different growing media on survival and growth of transplanted litchi layers
}

\section{WINEET CHAWLA AND KULDEEP MEHTA ${ }^{1}$}

ABSTRACT : A field experiment was conducted to study effect of different growing media on survival and growth of transplanted litchi layers at the Horticultural Regional Research Station, Dhaulakuan, Dr. Y. S. Parmar University of Horticulture and Forestry, Nauni, Solan Himachal Pradesh during the year 2011-2012. The results indicated that litchi orchard soil + FYM + PGPR @ 50g/kg growing media took earlier growth emergence after planting (105.98 days) and also gave better results with respect to all the parameters studied including survival percentage $(90.00 \%)$, increase in plant height $(10.65 \mathrm{~cm})$, number of leaves/layer (32.30), average leaf area $\left(25.50 \mathrm{~cm}^{2}\right)$, total leaf area $\left(823.45 \mathrm{~cm}^{2}\right)$, total root length $(14.27 \mathrm{~m})$, chlorophyll content $(0.91 \mathrm{mg} /$ $\mathrm{g}$ ), fresh and dry weight of roots ( 8.17 and $3.08 \mathrm{~g}$ ), fresh and dry weight of shoot (58.03 and 35.30 $\mathrm{g}$ ), root: shoot ratio on fresh and dry weight basis (0.141 and 0.087$)$, respectively.

KEY WORDS : PGPR, Growing media, Litchi layers

HOW TO CITE THIS ARTICLE : Chawla, Wineet and Mehta, Kuldeep (2015). Effect of different growing media on survival and growth of transplanted litchi layers. Asian J. Hort., 10(2) : 257-261. 